\title{
PEMETAAN TOPOGRAFI, GEOFISIKA DAN GEOLOGI KOTA SURABAYA
}

\author{
${ }^{1}$ Syaeful Bahri dan ${ }^{2}$ Madlazim \\ ${ }^{1}$ Physics Department, Faculty Mathematics and Science of ITS \\ Jl. Arif Rahman Hakim I, Surabaya 60111 \\ ${ }^{2}$ Physics Department, Faculty Mathematics and Science \\ of the State University of Surabaya (UNESA) \\ Jl. Ketintang, Surabaya 60231, Indonesia.
}

\begin{abstract}
Abstrak
Tujuan penelitian ini adalah diperolehnya suatu informasi tentang kondisi geologi, geofisika dan hidrogeologi di wilayah Kota Surabaya, diperolehnya kerangka acuan dalam pengambilan kebijakan perkotaan terkait mitigasi bencana maupun pembangunan kota berdasarkan potensi kebumian dan diperolehnya manfaat hasil-hasil penelitian bidang geologi dan geofisika bagi peningkatan kualitas hidup masyarakat Kota Surabaya. melalui tahap inventarisasi yang Untuk mencapai tujuan penelitian ini digunakan metode deskriptif melalui beberapa tahapan, yaitu tahap pengumpulan data sekunder dan studi literature yang meliputi; inventarisasi data geofisika, inventarisasi data geologi dan inventarisasi data seismologi yang meliputi pengumpulan data kegempaan dari tahun ke tahun yang merusak dan dirasakan penduduk Surabaya, data seismotektonik Surabaya. Tahap selanjutnya adalah kajian dan analisa data peta topografi dan geologi. Pada tahap ini yang dilakukan analisa/interpretasikan data dari peta dasar citra satelit resolusi tinggi, studi literatur dan kebijakan yang terkait. Pada tahap evaluasi dan pemetaan hasil, yang dilakukan adalah kompilasi, evaluasi dan interpretasi data geologi, geofisika dan hidrogeologi. Tahap akhir adalah merumuskan secara makro tentang arahan kebijakan mitigasi bencana dan pembangunan bawah bumi yang dapat dilakukan. Rekomendasi hasil penelitian ini adalah titik pertama lokasi di sebelah barat kampus Stikom Surabaya di Sebelah barat Kampus Stikom Surabaya. Di dapatkan pada kedalaman (0,44-5,48 dan 0,44-5,48) lapisan atas didominasi oleh selang seling lapisan aquiver asin dan payau. Aquiver produktif rendah sampai sedang (aquiver tawar) berupa pasir sisipan lempung, pasir, pasir sisipan kerikil. Diperkirakan aquiver ini berada di kedalaman mulai 25 hingga 100 meter. Titik kedua lokasi di Jl. Kenjeran - Mulyorejo Surabaya. Di dapatkan lapisan atas didominasi oleh selang seling lapisan aquiver asin, payau dan tawar. Akuifer produktif rendah sampai sedang berupa pasir sisipan lempung, pasir, pasir sisipan kerikil. Diperkirakan aquiver ini berada di kedalaman mulai 40 hingga 100 meter. Titik Ketiga Lokasi Jl. Raya Tandes Margomulyo Surabaya. Di dapatkan bahwa lapisan atas didominasi oleh lapisan aquiver asin. Berdasarkan gambar penampang tersebut terlihat bahwa terdapat dua batas antara lapisan aluvium dan formasi Kabuh, dan juga terlihat adanya fenomena dorongan pengisian siklus hidrologi yang menyusup melewati formasi Kabuh, mengingat formasi ini didominasi oleh lapisan lempung, pasir, kerikil dengan tingkat porositas sedang hingga tinggi. Aquiver tawar diduga berada di kedalaman mulai 40 hingga 100 meter.Titik Keempat di Timur Kampus UWK Surabaya. Di dapatkan bahwa lapisan atas didominasi oleh lapisan aquiver asin. Berdasarkan gambar penampang tersebut terlihat bahwa terdapat dua batas antara lapisan aluvium dan formasi Kabuh, dan juga terlihat adanya fenomena dorongan pengisian siklus hidrologi yang menyusup melewati formasi Kabuh.
\end{abstract}




\section{Latar Belakang}

Geofisika merupakan bagian dari ilmu bumi yang mempelajari bumi menggunakan kaidah atau prinsip-prinsip fisika. Penelitian geofisika diperlukan untuk mengetahui kondisi di bawah permukaan bumi melibatkan pendataan di atas permukaan bumi dari parameter-parameter fisika yang dimiliki oleh batuan di dalam bumi. Dari pendataan ini dapat ditafsirkan bagaimana sifat-sifat dan kondisi di bawah permukaan bumi baik itu secara vertikal maupun horisontal. Sedangkan geologi mempelajari lapisan batuan dari kulit bumi (atau litosfer) dan perkembangan sejarahnya.

Kota Surabaya sebagai kota terbesar kedua di Indonesia, telah mengalami perkembangan yang cukup pesat, baik dari segi fisik maupun non fisik. Dengan luas wilayah kota kurang lebih 33.048 ha, dimana $60,17 \%$ luas wilayah merupakan kawasan terbangun dan jumlah penduduk kurang lebih 3 juta jiwa, Kota Surabaya terus berkembang secara dinamis sebagai salah satu pusat regional dan nasional yang kompleks (BAPPEKO Surabaya, 2010). Pengembangan kota tidak hanya akan berkembang secara vertikal dan horisontal saja, tetapi juga akan memanfaatkan ruang bawah bumi baik untuk pembangunan infrastruktur bawah tanah maupun beragam fasilitas publik lainnya untuk efisiensi lahan kota yang semakin terbatas (Badan Lingkungan Hidup, 2010).

Pengembangan kota yang baik adalah yang dibuat dengan mempertimbangkan kondisi di bawah permukaan bumi. Struktur geologi dan kondisi geomorfologi perlu diperhatikan sehubungan dengan potensi bencana maupun kandungan sumberdaya mineral, dan tambang di wilayah kota tersebut yang bermanfaat untuk perkembangan kota (Daryono dkk., 2009; Nakamura dkk., 2000). Bencana alam geologi merupakan kejadian alam ekstrim yang diakibatkan oleh berbagai fenomena geologi dan geofisika (Jeng dkk., 2007; Tuladhar dkk., 2004). Aktivitas tektonik di permukaan bumi dapat menjadi salah satu penyebabnya, demikian halnya dengan aktivitas vulkanik di bawah permukaan bumi yang juga mungkin sampai di permukaan (Irsyam dkk., 2012; Siehaimi, 2008). Kerugian jiwa, material, dan budaya merupakan aspek utama yang berisiko menanggung dampak bencana. Kesadaran tentang potensi bencana di Kota Surabaya menjadi alasan utama perlunya dilakukan usaha-usaha ilmiah untuk memitigasinya. Selain itu perkembangan kota yang semakin massif memerlukan ruang yang lebih untuk menampung aktivitas warga yang semakin dinamis, sehingga ruang bawah bumi merupakan potensi ruang yang dapat dimanfaatkan untuk efisiensi penggunaan lahan (Mazzini, 2009; Sawolo dkk., 2009; Satyana, 2008).

Dalam rangka mitigasi bencana kebumian (gempa bumi, gerakan tanah, tsunami, dll) serta keperluan perencanaan pembangunan di bawah bumi, maka perlu dilakukan suatu kajian dan analisa geologi dan geofisika yang dapat memberikan informasi secara ilmiah tentang kebumian, berikut struktur, fenomena-fenomena yang terjadi, hingga kaitannya dengan manfaat bagi pembangunan di Kota Surabaya. Kajian ini juga penting sebagai dasar perumusan tindakan mitigasi bencana, dan kebijakan terkait pembangunan Kota Surabaya di masa yang akan datang yang juga akan memanfaatkan ruang bawah bumi sebagai ruang beraktivitas yang aman bagi warga kota.

\section{Gambaran Umum Kota Surabaya}

Gambaran umum kota Surabaya dapat dideskripsikan seperti berikut. Luas wilayah Kota Surabaya \pm 33.048 Ha. Wilayah Surabaya secara umum terbagim menjadi 4 wilayah yaitu Surabaya Pusat, Surabaya Timor, Surabaya Barat, Surabaya Utara, dan Surabaya Selatan. Secara administratif, Kota Surabaya terbagi dalam dalam 31 Kecamatan, 163 Kelurahan, 1.363 Rukun Warga, dan 8.909 Rukun Tetangga. Kota Surabaya memiliki ketinggian tanah antara $0-20$ meter di 
atas permukaan laut, sedangkan pada daerah pantai ketinggiannya berkisar antara 1-3 meter diatas permukaan laut. Sebagian besar Kota Surabaya memiliki ketinggian tanah antara $0-10$ meter $(80,72 \%$ atau sekitar $26.345,19 \mathrm{Ha})$ yang menyebar di bagian timur, utara, selatan dan pusat kota.

Wilayah kota Surabaya merupakan dominan daerah dataran rendah, yang berkisar $80 \%$ merupakan endapan alluvial dan sisanya merupakan perbukitan rendah yang dibentuk oleh tanah hasil pelapukan batuan tersier/tua. Dataran rendah meliputi wilayah Surabaya Timur, Utara dan Selatan memiliki kemiringan $<3 \%$ dan terletak pada ketinggian $<10 \mathrm{~m}$ dari permukaan laut. Dataran rendah terbentuk dari endapan alluvial sungai dan endapan pantai. Bagian tengah Kota Surabaya terbentuk oleh endapan Sungai Brantas beserta cabang-cabang sungainya dan endapan Sungai Rowo. Endapan Sungai Brantas berasal dari letusan gununggunung berapi yang berada di hulu dan beberapa rombakan sebellumnya. Endapan ini biasanya berupa pasir $(0,075 \mathrm{~mm}-0.2$ $\mathrm{mm})$ dan kerikil (2 mm - $75 \mathrm{~mm})$. Bagian timur dan utara sampai sepanjang Selat madura dibentuk oleh endapan pantai yang masuk ke daratan sampai $\pm 5 \mathrm{~km}$. Endapan pantainya terdiri dari lempung lanau dan lempung kelanauan, sisipan tipis tipis yang pada umumnya mengandung banyak kepingan kerang di beberapa tempat.

Secara geologi kota Surabaya terbentuk oleh batuan sedimen yang berumur Miosen sampai Plistosen. Batuan sedimennya adalah bagian dari lajur Kendeng dengan formasi Sonde, Lidah, Pucangan, dan formasi Kabuh. Batuan dasar untuk kota Surabaya merupakan formasi Lidah yang berumur Pliosen (pre-tertiary). Formasi ini berada pada kedalaman 250 - 300 meter. Selain itu derah Surabaya berupa cekungan endapan aluvial muda hasil endapan laut dan sungai, tuf dan batu pasir (Soekardi, 1992).

\section{Metode Peneletian}

Metode yang digunakan dalam penelitian ini adalah penelitian deskriptif karena dalam penelitian ini tidak memberikan perlakuan dan tidak memanipulasi variabel, tetapi penelitian ini memberi gambaran atau uraian tentang tomografi, geofisika dan geologi kota Surabaya sejernih mungkin berdasarkan data yang dikumpulkan dan hasil analisis data. Berdasarkan uraian tersebut selanjutnya dirumuskan rekomendasi arahan kebijakan mitigasi bencana dan pembangunan bawah bumi.

\section{Tahapan Pelaksanan Penelitian}

Penyusunan Kajian dan Analisa Potensi Geologi dan Geofisika Kota Surabaya dilakukan melalui tahapan-tahapan sebagai berikut: (1) Tahap Inventarisasi. Tahap inventarisasi adalah tahap awal dari kegiatan Penyusunan Inventarisasi pengumpulan data - data sekunder dan studi literature yang meliputi; Inventarisasi data geofisika yang meliputi pengumpulan data dari peta Curah hujan, Peta Intrusi air laut, Peta kecepatan angin, dan data peta lain di Kota Surabaya yang bisa menggambarkan potensi yang ada dan mungkin terjadi di Kota Surabaya. Inventarisasi data geologi yang meliputi pengumpulan data peta geologi yang meliputi: informasi sebaran, jenis dan sifat batuan, umur stratigrafi, struktur, tektonik, fisiografi dan potensi sumber data mineral. Inventarisasi data seismologi yang meliputi pengumpulan data kegempaan dari tahun ke tahun yang merusak dan dirasakan penduduk Surabaya, data seismotektonik Surabaya. (2) Tahap kajian dan analisa data peta topografi dan geologi Kota Surabaya. Pada tahap ini yang dilakukan adalah mengumpulkan, mengolah dan menganalisa/menginterpretasikan data dari peta dasar citra satelit resolusi tinggi, studi literatur dan kebijakan yang terkait. (3) Tahap pemetaan hasil. Pada tahap evaluasi dan pemetaan hasil, yang dilakukan adalah kompilasi, evaluasi dan interpretasi data geologi, geofisika dan hidrogeologi. (4) 
Tahap perumusan arahan kebijakan mitigasi bencana dan pembangunan bawah bumi. Pada tahap ini, akan dirumuskan secara makro tentang arahan kebijakan mitigasi bencana dan pembangunan bawah bumi yang dapat dilakukan di Kota Surabaya. Skema/bagan alur penelitian ini selengkapnya bisa dilihat pada Gambar 1 .

\section{TUJUAN:}

- Melakukan kajian tentang kondisi bawah permukaan Kota Surabaya berdasarkan data Geologi, Geofsika dan hidrogeologi

- Mendapatkan kerangka acuan dalam pengambilan kebijakan perkotaan berdasarkan informasi kebumian tentang geologi dan geofisika - Peningkatan Kualitas hidup masayrakat Kota Surabaya dari hasil penelitian bidang Geologi dan Geofisika

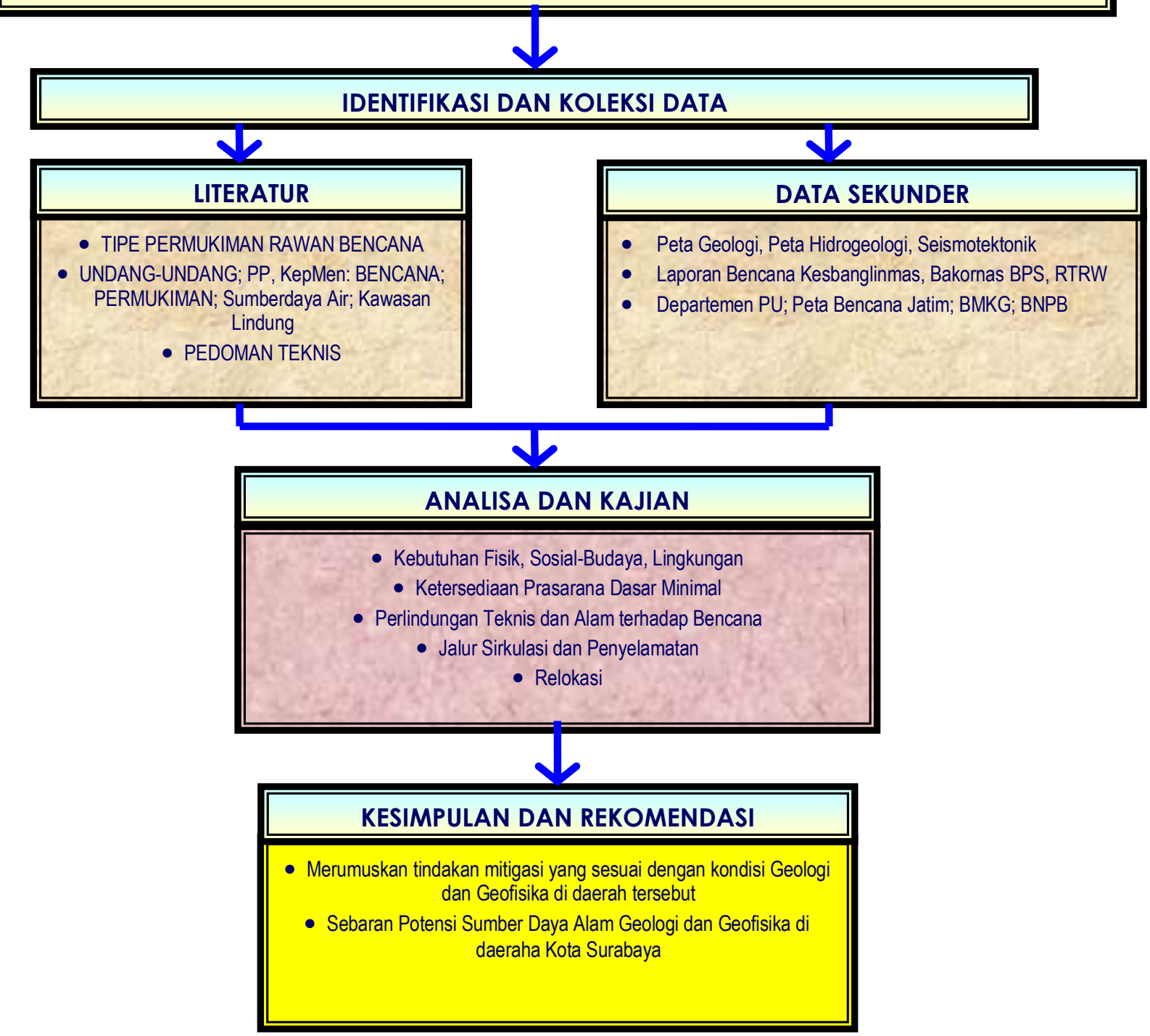

Gambar 1. Skema alur pikir penelitian

\section{Hasil dan Pembahasan}

Titik pertama lokasi di sebelah barat kampus Stikom Surabaya di Sebelah barat Kampus Stikom Surabaya. Di dapatkan pada kedalaman $(0,44-5,48$ dan $0,44-5,48)$ lapisan atas didominasi oleh selang seling lapisan aquiver asin dan payau. Aquiver produktif rendah sampai sedang (aquiver tawar) berupa pasir sisipan lempung, pasir, pasir sisipan kerikil. Diperkirakan aquiver 
ini berada di kedalaman mulai 25 hingga 100 meter. Titik kedua lokasi di Jl. Kenjeran - Mulyorejo Surabaya. Di dapatkan lapisan atas didominasi oleh selang seling lapisan aquiver asin, payau dan tawar. Akuifer produktif rendah sampai sedang berupa pasir sisipan lempung, pasir, pasir sisipan kerikil. Diperkirakan aquiver ini berada di kedalaman mulai 40 hingga 100 meter. Titik Ketiga Lokasi Jl. Raya Tandes Margomulyo Surabaya. Di dapatkan bahwa lapisan atas didominasi oleh lapisan aquiver asin. Berdasarkan gambar penampang tersebut terlihat bahwa terdapat dua batas antara lapisan aluvium dan formasi Kabuh, dan juga terlihat adanya fenomena dorongan pengisian siklus hidrologi yang menyusup melewati formasi Kabuh, mengingat formasi ini didominasi oleh lapisan lempung, pasir, kerikil dengan tingkat porositas sedang hingga tinggi. Aquiver tawar diduga berada di kedalaman mulai 40 hingga 100 meter.Titik Keempat di Timur Kampus UWK Surabaya. Di dapatkan bahwa lapisan atas didominasi oleh lapisan aquiver asin. Berdasarkan gambar penampang tersebut terlihat bahwa terdapat dua batas antara lapisan aluvium dan formasi Kabuh, dan juga terlihat adanya fenomena dorongan pengisian siklus hidrologi yang menyusup melewati formasi Kabuh.

\section{Kesimpulan dan Rekomendasi}

Satuan Geologinya daerah Surabaya di klasifikasikan menjadi 4 daerah yaitu : Endapan aluvial (Qa) penyebaran di sebagian besar wilayah Surabaya mulai dari bagian utara, selatan, timur dan di daerah sekitar pesisir pantai, sudah dibuktikan dengan adanya peninggalan sumur minyak tua di daerah Formasi Berdasarkan Peta Geologi Kota Surabaya terdapat dua antiklin yang membujur ke arah barat-timur yaitu antiklin lidah dan antiklin guyangan berpotensi besar sebgai cebakan hidrokarbon (minyak bumi) di Wonokromo. Lidah (Tpl) Persebaran
Formasi Lidah ini meliputi sebagian daerah Wonokromo, Sawahan, Dukuh Pakis, Lakarsantri, Wiyung dan Karangpilang, formasi Pucangan (Qtp) Penyebaran batuan dari formasi ini adalah berada di sekitar pusat kota menyebar ke arah barat dan selatan yang meliputi daerah Dukuh Pakis, Sawahan, Sukomanunggal Tandes, Wiyung, Lakarsantri, Karangpilang dan Gubeng, Formasi kabuh (Qpk) Formasi Kabuh ini meliputi sebagian wilayah Kecamatan Rungkut, Wonocolo, Tenggilis, Wiyung, Karangpilang, Lakarsantri, Tandes, Sukomanunggal, Benowo dan Dukuh Pakis. terdapat dua antiklin yang membujur ke arah barat-timur yaitu antiklin lidah dan antiklin guyangan berpotensi besar sebgai cebakan hidrokarbon (minyak bumi). Kondisi Geologi yang menarik di Surabaya adalah Mud Volcano (gunung lumpur) Gunung anyar. Keberadaanya berkaitan dengan minyak dan gas bumi, struktur patahan, dan potensi bencana.

\section{Ucapan Terima Kasih}

Ucapan terima kasih kami sampaikan kepada BAPPEKO Surabaya atas biaya yang diberikan untuk melakuakan penelitian ini. Terima kasih juga kami sampaikan kepada mahasiswa jurusan Fisika ITS yang telah membantu penelitian ini.

\section{Daftar Pustaka}

BAPPEKO Surabaya, 2010, Pemetaan Penurunan Permukaan Tanah Kota Surabaya.

Badan Lingkungan Hidup, 2010, Status Lingkungan Hidup Kota Surabaya.

Daryono dkk,2009, Efek Tapak Lokal (Local Site effect) di Graben Bantul Berdasarkan Pengukuran Mikrotremor. International Conference Earth Science And Technology. Yogyakarta 6-7 August 2009.

Jeng, Y., Lin, M.-J., Chen, C.-S., Wang, Y.-H. (2007). Noise reduction and data recovery for a very low frequency electromagnetic survey using the 
nonlinear decomposition method. Geophysics 72, F223-F235.

Masyur Irsam, 2012 Revisi Peta Gempa Indonesia 2010 - $2011 \quad$ Untuk Perencanangan Gedung dan Infrastruktur Tahan Gempa, , ITB.

Mazzini, A. (2009). Mud volcanism: Processes and implications. Marine and Petroleum Geology, Vol:26.pp:16771680.

Nakamura, Y., E. D. Gurler, J. Saita, A. Rovelli and S. Donati 2000, Vulnerability Investigation of Roman Colosseum using Microtremor, Proceedings of 12 th WCEE, New Zealand, \#2660.

Soehaimi, A, 2008, Seismotektonik dan Potensi Kegempaan Wilayah Jawa, , Jurnal Geologi Indonesia.
Soekardi,1992,Geologi Lembar Pacitan,Jawa,Pusat Penelitian dan Pengembangan Geologi Indonesia.

Tuladhar, R., Yamazaki, F., Warnitchai, P., Saita, J., 2004. Seismic microzonation of the greater Bangkok area using microtremor observations. Earthquake Engineering and Structural Dynamics 33.(2), 211-225.

Sawolo, N.,E. Sutriono, B.P. Istadi, B.D. Agung. 2009. The LUSI mud volcano triggering controversy: Was it caused by drilling?. Marine and Petroleum Geology, Vol:26, pp:1766-1784.

Satyana, 2008, 60 Basin Status of Indonesia.Laporan BP Migas 